\title{
Foreign Law, Democracy, and Constitutional Interpretation: A German-American Comparison
}

\author{
Shu-Perng Hwang*
}

(Received 17 April 2018; accepted 12 July 2018)

\begin{abstract}
Democracy is usually relied upon as an important argument against the excessive influence of international and foreign law on the domestic legal order, and especially on domestic constitutional law. Both in Germany and the United States, skeptics and opponents of the Europeanization or internationalization of domestic constitutional law repeatedly raise democratic concerns. From a comparative perspective, this Article examines the German and American democratic arguments against an overreliance on international and foreign law in constitutional interpretations. In exploring the democratic concerns expressed in German and American discussions, this Article focuses especially on the contrast between German dualism on the one hand and American exceptionalism on the other hand. This Article shows that, while the German dualists and the American exceptionalists base their arguments on different understandings of democracy, they share the viewpoint that democracy can only be realized on the national level, whereas international law aims at uniformity und thus inevitably runs counter to democratic self-governance and self-determination of the states. Precisely in this sense, it can be said that there is no qualitative, but rather only a quantitative distinction between German and American democratic arguments. Thus conceived, the alleged contrast between the principle of open statehood emphasized by German constitutional law scholars and the Constitutional Court and the idea of American exceptionalism embraced by a number of critics of the use of foreign law lies only in the extent to which the reference to international or foreign law in interpreting the domestic Constitution is deemed legitimate and justifiable.
\end{abstract}

Keywords: foreign law; democracy; dualism; (American) exceptionalism; constitutional identity

\section{A. Introduction}

It is no surprise that in the age of globalization, democracy is usually relied upon as an important argument against the excessive influence of international and foreign $\operatorname{law}^{1}$ on the domestic legal order, and especially on domestic constitutional law. Both in Germany and the United States, skeptics and opponents repeatedly raise democratic concerns with regard to the trends toward further Europeanization or internationalization of domestic constitutional law. Therefore, to confine the increasing binding force of international law, and especially European law to a limited range,

\footnotetext{
${ }^{*}$ Research Professor of Law, Institutum Iurisprudentiae, Academia Sinica.

${ }^{1}$ Borrowing the definition by Ganesh Sitaraman, the following discussion in this Article "uses the term foreign law to refer to two types of law: the domestic law of foreign states and international law." Ganesh Sitaraman, The Use and Abuse of Foreign Law in Constitutional Interpretation, 32 HARV. J.L. \& PUB. POL'y 653, 656 n.12 (2009). For a similar definition, see Austen L. Parrish, Storm in a Teacup: The U.S. Supreme Court's Use of Foreign Law, 2007 U. ILL. L. REV. 637, 638-52 (2007). When this Article uses the term "international law," however, it refers specifically to international law in the traditional sense, which mainly includes international treaties and customary international law and in general also encompasses supranational law, such as European Union law.
}

(C) The Author(s) 2019. Published by Cambridge University Press on behalf of the German Law Journal. This is an Open Access article, distributed under the terms of the Creative Commons Attribution licence (http://creativecommons.org/licenses/by/4.0/), which permits unrestricted re-use, distribution, and reproduction in any medium, provided the original work is properly cited. 
it is often argued among German constitutional law scholars that only the domestic Constitution could be recognized as the expression of popular sovereignty and democratic will. Accordingly, this argument purports that the Constitution must enjoy ultimate supremacy in relation to international law, which inevitably suffers from a democratic deficit. In reaction to the seemingly increasing use of foreign law in the constitutional interpretation of the Supreme Court of the United States some, if not most, American constitutional law scholars insist that no foreign resources should affect the interpretation of the American Constitution, because the American Constitution could, and should, only reflect the democratic will of the American people.

To the extent that the irreplaceable democratic significance of the domestic constitutional order has been emphasized by German as well as American skeptics, the German and American legal communities seem to share the viewpoint that the normative role of foreign law in the domestic constitutional order is subject to democratic constraints. Nevertheless, a closer look reveals that the democratic arguments advanced in these two countries have developed in varying ways. For example, while Germany's mainstream opinion has focused on the inseparable relationship between nation states and democracy, many American critics have emphatically highlighted the unique characteristics of American democracy. In addition, while most German scholars insist predominantly on the absolute supremacy of the German Constitution, a few American scholars even argue that the Supreme Court of the United States should refrain from referring to any foreign resources in interpreting the American Constitution. These preliminary observations already indicate that, in defending democracy against Europeanization, internationalization, and globalization, the German and American democratic arguments may be based on different understandings of democracy, which then may lead to different attitudes toward the relationship between foreign law and domestic constitutional law.

This Article intends to examine the democratic arguments against foreign law through a comparison between the democracy-based discussions advanced in Germany and the United States. Part B begins with the analysis of the concept of democracy from the viewpoint of Germany's mainstream opinion and aims to explore how this concept has contributed to the insistence on an absolute supremacy of domestic constitutional law. Part $\mathrm{C}$ goes on to elucidate the democratic arguments advanced by those who explicitly or implicitly embrace the idea of "American exceptionalism" so as to illuminate the characteristics of the American resistance to foreign law. The contrasts between Germany and the United States are then followed by a comparative analysis in Part D. In addition to examining the respective problems of these democratic arguments in Germany and the United States, this analysis also aims to illustrate one common myth shared by most democracy-based approaches in both countries; namely the notion that the idea of universalism underlying the development of the international legal community and transnational judicial dialogue inevitably runs counter to democracy, which is by its nature state-centered, and therefore anti-universalistic. Part E concludes.

\section{B. Democratic Concerns About the Impact of Europeanization and Internationalization on the Supremacy of the Constitution in Germany}

\section{The Inseparable Relationship Between State and Democracy}

Although it has long been widely recognized in Germany that the German Basic Law is characteristic of its commitment to international cooperation, and especially to European integration, most German constitutional law scholars adhere to the idea that the principle of open statehood ("offene Staatlichkeit") must not be confused with the relativization, or even erosion, of national sovereignty. ${ }^{2}$ Rather, as the Constitutional Court of the Federal Republic of Germany puts it,

\footnotetext{
${ }^{2}$ See, e.g., Udo Di Fabio, Der Verfassungsstaat in Der Weltgesellschaft 86-99 (2001); Josef Isensee, Der Selbstand der Verfassung in ihren Verweisungen und Öffnungen, 138 ARCHIV DES ÖFFENTLICHEN ReCHTS 325, 344-60 (2013).
} 
The Basic Law is clearly based on the classic idea that the relationship of public international law and domestic law is a relationship between two different legal spheres and that the nature of this relationship can be determined from the viewpoint of domestic law only by domestic law itself; this is shown by the existence and the wording of Article 25 and Article 59.2 of the Basic Law. The commitment to international law takes effect only within the democratic and constitutional system of the Basic Law. ${ }^{3}$

According to mainstream opinion in Germany, international law and domestic law are different in nature not only because international law, unlike domestic law, principally regulates the relationship among nations, but in particular because the domestic constitutional orders of democratic states express the popular sovereignty of their own people and are thus characteristic of their democratic significance. ${ }^{4}$ Therefore, the qualitative distinction between international and domestic law suggests that, to prevent a loss of sovereignty, the domestic legal order can neither be replaced by international law, nor be automatically penetrated by any international legal norms. In view of the irresistible trend toward European integration - which inevitably challenges the traditional view on international law-many German constitutional law scholars feel it necessary to underscore the distinction between European Union law and international law. ${ }^{5}$ This is done to safeguard constitutional democracy against the far-reaching influence of Europeanization. While international law_-including the European Convention on Human Rights ("the Convention") generally enjoys the same rank as a federal statute in the German legal system-as long as it fulfills certain conditions provided by the Basic Law-European Union law is recognized specifically as supranational law, and accordingly has primacy over the law of the member states when a conflict of laws arises. ${ }^{6}$ On the one hand, this distinction underlines the special role of European Union law in the German legal system. On the other hand, though, it shows that - while acknowledging the reality-German mainstream opinion attempts to limit the impact of Europeanization and internationalization through clarifying the different roles of different types of international law in the domestic legal system. Therefore, even though European Union law enjoys primacy over the domestic law, it is repeatedly asserted that such a primacy is not equivalent to supremacy, because the relationship between European Union law and domestic law cannot simply be understood as a hierarchy of norms. ${ }^{7}$ Moreover, as far as other international

\footnotetext{
${ }^{3}$ Bundesverfassungsgericht [BVerfG] [Federal Constitutional Court], Case No. 2 BvR 1481/04, § 34, (Oct. 14, 2004), https:// www.bundesverfassungsgericht.de/e/rs20041014_2bvr148104en.html (last visited Apr. 2, 2018).

${ }^{4}$ See, e.g., Udo Di Fabio, Eine europäische Charta. Auf dem Weg zur Unionsverfassung, 55 JurIsTEN ZeITUnG 737, 738, 74243 (2000); Di FABIO, supra note 2, at 91-92; Andreas Funke, Der Anwendungsvorrang des Gemeinschaftsrechts - einige Problemfälle und ein Präzisierungsvorschlag, 60 Die Öffentliche Verwaltung 733, 736 (2007); Dieter Grimm, Die Zukunft der Verfassung II: Auswirkungen von EuropÄIsIERUng und Globalisierung 92, 98-102, 120-23 (2012).

${ }^{5}$ See, e.g., Dieter Grimm, Constitutionalism: Past, Present, and Future 274 (2016).

${ }^{6}$ For the different status of the European Convention on Human Rights and European Union law in the constitutional order of German Basic Law, see Andreas Voßkuhle, Der europäische Verfassungsgerichtsverbund, 29 NEUE ZEITSCHRIFT FÜR VerwaltungSReCht 1, 3-4 (2010); Johannes Masing, Einheit und Vielfalt des Europäischen Grundrechtsschutzes, 70 Juristen ZeItung 477, 477-78 (2015); Dieter GrimM, "ICH BIN EIN Freund Der Verfassung": WissensChafts-


166-68 (2017). For a critical analysis of Germany's mainstream viewpoint on the rank and binding force of international law as well as supranational law in the German legal system, see Shu-Perng Hwang, Trägt die (begrenzte) Völkerrechtsfreundlichkeit als Verfassungsprinzip zum Ausgleich zwischen internationaler Zusammenarbeit und nationaler Souveränität bei? Zugleich Anmerkung zur "Treaty Override”-Entscheidung des BVerfG, 55 ARCHIV DES VÖLKERRECHTS 349, 365-74 (2017).

${ }^{7}$ See, e.g., Grimm, supra note 5, at 281, 285; Dana Burchardt, Die RANGFrage IM EUROPÄISCHEN NormENVERBUND:

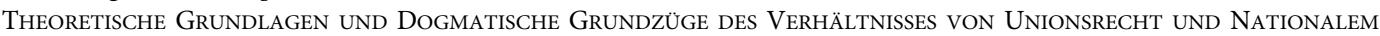
RECHT 27-32 (2015); Franz C. Mayer, Verfassung im Nationalstaat: Von der Gesamtordnung zur europäischen Teilordnung? [The Constitution in the Nation State: From the Overall Order to the European Order?], 75 VeröfFentlichungen der Vereinigung Der Deutschen StaAtsRechtslehrer 7, 23, 28-38 (2016); Karl-Heinz Ladeur, Europa kann nur als Netzwerk, nicht als "Superstaat" gedacht werden, in STRUKTURFRAGEN DER EUROPÄISCHEN UNION 119, 133
} 
norms - such as the Convention - are concerned, it is widely accepted that their binding force is limited due to their formal rank in the domestic legal order ${ }^{8}$ even though they may serve the function of "interpretative tools" ("Auslegungshilfe") in "determining the content and scope of fundamental rights and constitutional principles of the Basic Law."

More importantly, the discussions following from this distinction suggest that the German mainstream opinion has never abandoned the classic idea of national sovereignty, which above all, is characteristic of the adherence to the so-called dualistic view on the relationship between international law and domestic law, ${ }^{10}$ and thus to the inviolability of domestic constitutional identity. ${ }^{11}$ Accordingly, the principle of open statehood does not challenge dualism at all. Rather, it reinforces the idea that the domestic constitutional order-while open to international cooperation and interaction-occupies an even more important role in the age of internationalization as the social prerequisites for a functioning and vibrant democracy can only be developed on the domestic level. ${ }^{12}$ As Dieter Grimm puts it:

Even when we take note of the democratic deficits in the member states, they still have relatively dense civil-society structures, effective mechanisms for mediating between citizens and state institutions, and a broad array of media that maintains the flow of communication between state and society and thus imbues the legitimation and responsibility relationship

(Claudio Franzius et al. eds., 2010); Armin von Bogdandy, Pluralism, Direct Effect, and the Ultimate Say: On the Relationship Between International and Domestic Constitutional Law, 6 INT'L J. ConsT. L. 397, 397-401 (2008); Ingolf Pernice, Europäisches und nationales Verfassungsrecht, 60 VERÖFFENTLICHUNGEN DER VEREINIGUNG DER DEUTSCHEN STAATSRECHTSLEhrer 148, 185 (2001); Funke, supra note 4, at 735-36.

${ }^{8}$ See, e.g., Ferdinand Wollenschläger, Art. 25, in GrundgeSETZ-Kommentar, BD. I $§ 27$ (Horst Dreier ed., 3d ed. 2015); Matthias Herdegen, Europarecht 44 (18th ed. 2016).

${ }^{9}$ See 2 BvR 1481/04, supra note 3, at $\S 32$.

${ }^{10}$ For such an understanding of sovereignty, see GRIMM, supra note 5, at 318 ("Externally, [sovereignty] designated the right to determine domestic conditions free from the interference of other states."). Hans Kelsen accordingly described this view as "[m] onism with primacy of national law." HANS Kelsen, DAS Problem Der SOUverÄNitÄt UND DIE TheORIE DES Völkerrechts; Beitrag ZU einer Reinen Rechtslehre 120-59 (Scientia Verlag eds., 1981) (1920). Hans Kelsen, Principles of International LaW 553-80 (Robert W. Tucker ed., 2d ed. 1966) [hereinafter Kelsen, PrinciPles of International Law]. Hans Kelsen, Reine Rechtslehre: Einleitung in die rechtswissenschaftliche Problematik 147-52 (Mohr Siebeck 2008) (1934) [hereinafter KeLSEN, Reine ReChtSLEHRE].

${ }^{11}$ See discussion infra Part B.II.

${ }^{12}$ See also Bundesverfassungsgericht [BVerfG] [Federal Constitutional Court], Case No. 2 BvE 2/08, § 250-51, (June 30, 2009), https://www.bundesverfassungsgericht.de/e/es20090630_2bve000208en.html (last visited Jun. 27, 2018):

Democracy first and foremost lives on, and in, a viable public opinion that concentrates on central acts of determination of political direction and the periodic allocation of highest-ranking political offices in the competition of government and opposition. Only this public opinion shows the alternatives for elections and other votes and continually calls them to mind also in decisions relating to individual issues in order that they may remain continuously present and effective in the political opinion-formation of the people via the parties, which are open to participation for all citizens, and in the public information area ...

Even if due to the great successes of European integration, a common European polity that engages in issuerelated cooperation in the relevant areas of their respective states is visibly growing, it cannot be overlooked, however, that the public perception of factual issues and of political leaders remains connected to a considerable extent to patterns of identification related to the nation-state, language, history and culture ...

It is worth noting, though, that while this statement of the Constitutional Court reflects mainstream opinion in Germany, it has been criticized by a number of commentators for adhering to a conception of democracy that is based on homogeneity. See, e.g., Jo Eric Khushal Murkens, Identity Trumps Integration. The Lisbon Treaty in the German Federal Constitutional Court, 48 DER StAat 517, 521, 530 (2009); Martin Nettesheim, Die Karlsruher Verkündigung - Das BVerfG in Staatsrechtlicher Endzeitstimmung, in GRUNDGESETZ UND EUROPÄISCHE INTEGRATION: DiE EUROPÄISCHE UNION NACH DEM LISSABONURTEIL DES BundeSVERFASSUNGSGERICHTS, EuR BeIHEFT 1/2010 101, 117 (Armin Hatje \& Jörg Philipp Terhechte eds., 2010); Christoph Möllers, Fragmentierung als Demokratieproblem?, in STRUKTURFRAGEN DER EUROPÄISCHEN UNION 150, 151 (Claudio Franzius et al. eds., 2010); Shu-Perng Hwang, Demokratie im Mehrebenensystem: Integrationsfest oder integrationsoffen? Überlegungen zum Demokratiebegriff beim Lissabon-Urteil des BVerfG im Lichte des Schmitt-KelsenGegensatzes, 4 RECHTSWISSENSCHAFT 166, 168-79 (2013). 
intended by constitutional law with life so that overall, one could, at any rate, speak of a material, and not merely a formal democracy.

In the EU, by contrast, these social prerequisites for a functioning democracy are only weakly developed or are lacking entirely. Political communications as a fundamental condition of democracy is still largely determined by national interests and habits and stops at the national borders. $^{13}$

According to a dualistic view, therefore, neither European Union law nor international law are allowed to alter the central status of the state in the international legal community. This is because only the state is able to fulfill the requirements of modern democracy and in this way retain the value of democracy. In other words, the state remains "the most important source of legitimation, including the legitimation of international organizations," ${ }^{14}$ because the state and democracy are inseparable. ${ }^{15}$ Consequently, both European Union law and international law are to be regarded merely as "external law" that differs from domestic law not only in a formal sense, but also, and especially, from a democratic perspective.

\section{The Absolute Supremacy of the Constitution}

Precisely based on the democratic significance of the domestic constitutional order, the principles of openness towards international law ("Völkerrechtsfreundlichkeit") and European law ("Europarechtsfreundlichkeit") ${ }^{16}$ not merely presuppose the central role of the German Basic Law in determining the respective rank and status of international law and European Union law in the domestic legal system of the Federal Republic of Germany, but help guarantee the unconditional supremacy of the German Basic Law over international and European Union law. ${ }^{17}$ With respect to the relation to international law, therefore, the German mainstream opinion tends to regard reference to international law in interpreting the Constitution as a method which is part of, or at least similar to, comparative constitutional interpretation. ${ }^{18}$ Such a viewpoint indicates that, even in the case of the Convention, where the interpretation of Convention rightsespecially by the European Court of Human Rights-may affect the interpretation of the Basic Law, the international law can never trump the domestic constitutional law. On the contrary, the formal rank - as well as the binding force of the international human rights law-is to be determined by the Basic Law. Viewed this way, the special function of the Convention as an interpretation aid on the level of constitutional law does not result from its universal significance for

\footnotetext{
${ }^{13}$ GrIMM, supra note 5, at 293.

${ }^{14}$ GRIMM, supra note 5 , at 376 .

${ }^{15}$ According to the German mainstream opinion, the nation states are more capable of fulfilling the promise of democracy than inter- and supranational organizations mainly because they enable public discourse in a real sense. It is thus not surprising that some if not most German scholars still embrace the idea that a certain degree of homogeneity is required for a functioning democracy. See, e.g., Dieter Grimm, Braucht Europa eine Verfassung?, 50 JURISTEN ZEUITUNG 581 (1995) reprinted in Die Verfassung und die Politik: Einsprüche IN STÖrfällen 215, 248-49 (2001); Ernst-Wolfgang Böckenförde, Demokratie als Verfassungsprinzip, in HANDBUCH DES STAATSRECHTS DER BUNDESREPUblik DeUTSCHLAND, BD. II: VerfassungsstaAt § 63 (Josef Isensee \& Paul Kirchhof eds., 3d ed. 2004); Josef Isensee, Die Staatlichkeit der Verfassung, in Verfassungstheorie 199, 265-69 (Otto Depenheuer \& Christoph Grabenwarter eds., 2010).

${ }^{16}$ It is widely accepted in Germany that this openness towards international law and European law qualifies as a constitutional principle. See generally Mehrdad Payandeh, Völkerrechtsfreundlichkeit als Verfassungsprinzip. Ein Beitrag des Grundgesetzes zur Einheit von Völkerrecht und nationalem Recht, 57 JAHRBUCH DES ÖFFENTLICHEN RECHTS DER GEgENWART 465, 466, 481-83 (2009); DANIEL KNOP, VÖLKER- UND EUROPARECHTSFreundLICHKEIT ALS VerfassungsgrundsätZe 4-5, 345-46 (2013); Matthias Herdegen, GG Art. 25, in Grundgesetz-Kommentar § 6-7 (Theodor Maunz \& Günter Dürig Begr., 77. Ergänzungslieferung 2016).

${ }^{17}$ See also Hwang, supra note 6, at 364-66.

${ }^{18}$ See Bundesverfassungsgericht [BVerfG] [Federal Constitutional Court], Case No. 2 BvR 2365/09, § 91-92, (May 4, 2011), https://www.bundesverfassungsgericht.de/e/rs20110504_2bvr236509en.html (last visited Apr. 2, 2018).
} 
human rights protection, but from Article 1.2 of the Basic Law providing that the German people "acknowledge inviolable and inalienable human rights as the basis of every community, of peace and of justice in the world." 19 Therefore, in recognizing the fundamental rights guaranteed in the Basic Law as "a manifestation of human rights," the Constitutional Court of Germany reaffirmed the supremacy of the German Basic Law over the Convention in its decision on Sicherungsverwahrung in 2011. As the Court said:

Invoking the European Convention on Human Rights as an interpretation aid for the provisions of the Basic Law is results-oriented, as is the European Convention on Human Rights itself with regard to its enforcement in national law. It does not aim at a schematic parallelization of individual constitutional concepts, but serves to avoid violations of international law ...

Against this background something similar is true of an interpretation of the concepts of the Basic Law that is open to international law as of an interpretation based on a comparison of constitutions: similarities in the text of the norm may not be permitted to hide differences which follow from the context of the legal systems: the human rights content of the agreement under international law under consideration must be 'reconceived' in an active process (of reception) in the context of the receiving constitutional system.

Limits to an interpretation that is open to international law follow from the Basic Law. In the first instance, such an interpretation may not result in the protection of fundamental rights under the Basic Law being restricted; this is also excluded by the European Convention on Human Rights itself. This obstacle to the reception of law may become relevant above all in multi-polar fundamental rights relationships in which the increase of liberty for one subject of a fundamental right at the same time means a decrease of liberty for the other. The possibilities of interpretation in a manner open to the Convention end where it no longer appears justifiable according to the recognized methods of interpretation of statutes and of the constitution. Furthermore, even where the Basic Law is interpreted in a manner open to the Convention - just as when the case-law of the European Court of Human Rights is taken into account on the level of ordinary law - the case-law of the European Court of Human Rights must be integrated as carefully as possible into the existing, dogmatically differentiated national legal system, and therefore an unreflected adaptation of international-law concepts must be ruled out. ${ }^{20}$

Remarkably, the Constitutional Court's insistence on the supremacy of the Basic Law is not exhausted in the relation to international law. As mentioned before, in response to the general recognition of the primacy of European Union law over domestic law-including domestic constitutional law - the mainstream opinion in Germany insists that the legal system of the European Union does not constitute a hierarchy of norms with the supremacy of European Union law. ${ }^{21}$ This view makes it so that the alleged priority of European Union law is not one of validity, but merely of application (so-called "Anwendungsvorrang"). ${ }^{22}$ Accordingly, in its decision on

\footnotetext{
${ }^{19}$ See also Frank Hoffmeister, Die Europäische Menschenrechtskonvention als Grundrechtsverfassung und ihre Bedeutung in Deutschland, 40 Der StaAt 349, 372 (2001); Horst Dreier, Art. 1 II, in Grundgesetz-Kommentar, BD. I § 20 (Horst Dreier ed., 3d ed. 2013). For a critical overview, see Shu-Perng Hwang, Die EMRK im Lichte der Rechtsprechung des BVerfG: Die Entwicklung eines Grundrechtspluralismus zur Überwindung des Gegensatzes von Monismus und Dualismus?, 52 EUROPARECHT 512, 521-22 (2017).

${ }^{20} 2$ BvR 2365/09, supra note 18 , at $\$ \$ 91-94$.

${ }^{21}$ See discussion supra Part B.I.

${ }^{22}$ See, e.g., Matthias Herdegen, Europarecht 222-27 (16th ed. 2014); Rudolf Streinz, Europarecht § 220 (9th ed. 2012); Hartmut Maurer, Der Anwendungsvorrang im Normensystem, in DER GRUNDRECHTSGEPRÄGTE VERFASSUNGSSTAAT: Festschrift Für KLAus Stern Zum 80. Geburtstag 101, 102-03 (Michael Sachs \& Helmut Siekmann eds., 2012); Franz C. Mayer, Europäisches Verwaltungsrecht und nationales Verfassungsrecht, in VERWALTUNGSRECHT DER EUROPÄISCHEN UnION §§ 42-49 (Jörg Philipp Terhechte ed., 2011); Matthias Ruffert, Art. 1 AEUV, in EUV/AEUV: DAS
} 
the Lisbon Treaty in 2009, the Constitutional Court of Germany held that the core content of the constitutional identity of the Basic Law is inviolable even in recognition of the primacy of application of European Union law. ${ }^{23}$ Moreover, in the decision on the European arrest warrant in 2015, the Constitutional Court made it more clear that the scope of such primacy is limited by the Basic Law's constitutional identity. As the Court said:

To the extent that acts of an institution or an agency of the European Union have an effect that affects the constitutional identity protected by Art. 79 sec. 3 GG in conjunction with the principles laid down in Arts. 1 and 20 GG, they transgress the limits of open statehood set by the Basic Law. Such an act cannot be based on an authorization under primary law, because the legislature deciding on European integration matters, despite acting with the majority required by Art. $23 \mathrm{sec}$. 1 sentence 3 GG in conjunction with Art. 79 sec. 2 GG, cannot transfer sovereign powers to the European Union which, if exercised, would affect the constitutional identity protected by Art. 79 sec. 3 GG. Nor can it be based on initially constitutional conferrals that have supposedly evolved through a development of the law, because the institution or the agency of the European Union would thereby act ultra vires. ${ }^{24}$

To this extent, it can be said that while European Union law possesses primacy of application in general, the Basic Law's constitutional identity enjoys unconditional supremacy over European Union law. According to the reasoning of the Constitutional Court, this is so, not only because the guarantee of the Basic Law's constitutional identity safeguards the protection of human rights and, in particular, human dignity, ${ }^{25}$ but because the Federal Republic of Germany-like other member states of the European Union-remains the "master of the treaty." 26 Precisely in this context, therefore, it is no surprise that the Constitutional Court chose not to stress the special character of the European Union as a supranational entity, but rather the nature of European Union law as international law, that is to say, as external law. ${ }^{27}$

VERfASSUNGSRECHT DER EUROPÄISCHEN UNION MIT EUROPÄISCHER GRUNDRECHTECHARTA § 16 (Christian Calliess \& Matthias Ruffert eds., 4th ed. 2011).

${ }^{23}$ See 2 BvE 2/08, supra note 12 , at $§ 240$ :

Furthermore, the Federal Constitutional Court reviews whether the inviolable core content of the constitutional identity of the Basic Law pursuant to Article 23.1 third sentence in conjunction with Article 79.3 of the Basic Law is respected. The exercise of this review power, which is rooted in constitutional law, follows the principle of the Basic Law's openness towards European Law (Europarechtsfreundlichkeit), and it therefore also does not contradict the principle of sincere cooperation (Article 4.3 Lisbon TEU); otherwise, with progressing integration, the fundamental political and constitutional structures of sovereign Member States, which are recognized by Article 4.2 first sentence Lisbon TEU, cannot be safeguarded in any other way. In this respect, the guarantee of national constitutional identity under constitutional and under Union law go hand in hand in the European legal area. The identity review makes it possible to examine whether due to the action of European institutions, the principles under Article 1 and Article 20 of the Basic Law, declared inviolable in Article 79.3 of the Basic Law, have been violated. This ensures that the primacy of II of Union law only applies by virtue and in the context of the constitutional empowerment that continues in effect.

${ }^{24}$ Bundesverfassungsgericht [BVerfG] [Federal Constitutional Court], Case No. 2 BvR 2735/14, § 42, (15 Dec. 2015), https://www.bundesverfassungsgericht.de/e/rs20151215_2bvr273514en.html (last visited Apr. 2, 2018).

${ }^{25} \mathrm{Id}$. at $\$ 49$.

${ }^{26}$ See id. at $\$ 44$ :

The European Union is an association of sovereign states (Staatenverbund), of constitutions (Verfassungsverbund), of administrations (Verwaltungsverbund) and of courts (Rechtsprechungsverbund). This structure is ultimately based on international treaties concluded between the Member States. As "masters of the treaties" (Herren der Verträge), Member States decide through national legal arrangements if and to what extent Union law is applicable and is accorded precedence in the respective national legal order.

${ }^{27}$ See also Shu-Perng Hwang, Vorrang der Verfassungsidentität als Herausforderung für die Rechtsordnung der Europäischen Union?, 56 Der StAAT 107, 112-14 (2017). 
As a whole, the mainstream opinion in Germany, led by the decisions of the Constitutional Court, constantly seeks to find a balance between the constitutional principle of open statehood and the protection of the constitutional identity of the Basic Law. Consequently, it welcomes substantial influences of international law and European law on the interpretation of the Basic Law, and at the same time adheres to the absolute supremacy of the Basic Law, and especially of the core content of its constitutional identity. In particular, many constitutional law scholars in Germany believe that - in view of the inseparable relationship between state and democracy-only the supremacy of the Basic Law over supra- and international norms ensures the supremacy of the democratic self-determination of the German people. ${ }^{28}$ Furthermore, it is worth noting that the insistence on the absolute supremacy of the Basic Law is usually accompanied by the emphasis on the significant role of the Constitutional Court of Germany in safeguarding democracy in Germany. While the Constitutional Court has been criticized for exceeding the limits of its competence and, especially, for invading the power of the democratically legitimated legislators in numerous domestic separation-of-powers debates, ${ }^{29}$ in external relations it is usually regarded as the guardian of the Basic Law, and thus, of democracy-particularly through its identity review. ${ }^{30}$

\section{Democratic Concerns About the Use of Foreign Law in Constitutional Interpretation in the United States}

\section{1. "American Exceptionalism"}

As indicated previously, democratic concerns about the influence of international law on domestic constitutional law are expressed not only in Germany, but also in the United States. For many American constitutional law scholars, the Constitution of the United States is regarded as an essential expression of the democratic self-determination of its people. Unlike the German mainstream opinion, the American skeptics have never built their democratic arguments on the basis of the alleged principle of open statehood. Rather, they tend to rely on an understanding of democracy that is antagonistic to the idea of openness toward transnational interaction through reference to international resources. Moreover, for some of those who simply reject any foreign influences on the interpretation of the U.S. Constitution, such an understanding of democracy may only apply to the United States. To this extent, it can be said that, in comparison to the democratic concerns of the German mainstream opinion, the democratic arguments advanced by many American opponents of the use of foreign law in constitutional interpretation are developed under the influence of the so-called "American exceptionalism."

\footnotetext{
${ }^{28}$ See, e.g., Paul Kirchhof, Die Identität der Verfassung, in HANDBUCH DES STAATSRECHTS Der BundesRePUblik Deutschland, BD. II: Verfassungsstaat §§ 72-75, 79-82 (Josef Isensee \& Paul Kirchhof eds., 3d ed. 2004); Josef Isensee, Vorrang des Europarechts und deutsche Verfassungsvorbehalte - offener Dissens, in VERFASSUNGSSTAATLICHKEIT: FeSTSChrift FÜr Klaus Stern ZUM 65. Geburtstag 1239, 1261-65 (Joachim Burmeister ed., 1997).

${ }^{29}$ For relatively recent discussions on this constantly debated issue, see MATTHIAS JeSTAEDT, OLIVER LEPSIUS, CHRISTOPH Möllers \& Christoph Schönberger, DAs entgrenzte Gericht: Eine kritische Bilanz NaCh SECHZig Jahren Bundesverfassungsgericht (2011); Shu-Perng Hwang, Das Bundesverfassungsgericht im Schnittpunkt zwischen Recht und Politik - ein unlösbares Problem?, 46 ReCHTSTHEORIE 179 (2015).

${ }^{30}$ See, e.g., Dieter GRIMm, Zur Rolle der nationalen Verfassungsgerichte in der europäischen Demokratie, in DIE ZUKUNFT DER Verfassung II: Auswirkungen von Europäisierung und Globalisierung 128, 151-52 (2012); Peter M. Huber, Bewahrung und Veränderung rechtsstaatlicher und demokratischer Verfassungsstrukturen in den internationalen Gemeinschaften - 50 Jahre danach, 141 ARCHIV DES ÖFFENTLICHEN RECHTS 117, 126-27 (2016); Hans-Georg Dederer, Die Grenzen des Vorrangs des Unionsrechts - Zur Vereinheitlichung von Grundrechts-, Ultra-vires- und Identitätskontrolle, 69 JURISTEN ZEITUNG 313, 316, 321-22 (2014).

${ }^{31}$ For the idea of American exceptionalism and its influence on the American attitude towards the use of foreign law in constitutional interpretation, see generally Harold Hongju Koh, On American Exceptionalism, 55 STAN. L. REV. 1479 (20022003) [hereinafter Koh, On American Exceptionalism]; Harold Hongju Koh, America's Jekyll-and-Hyde Exceptionalism, in AMERICAN EXCEPTIONALism AND Human Rights 111 (Michal Ignatieff ed., 2005) [hereinafter Koh, America's
} 
To put it simply, American exceptionalism refers to the uniqueness of the United States in comparison with all other nations, including the developed ones. ${ }^{32}$ Based on its unique political, cultural, and religious traditions, the United States regards itself as a leader rather than a follower in the world community, and thereby tends to resist rules and standards developed elsewhere. As Michael Ignatieff observes: "[U]nder some administrations, it has promoted human rights as if they were synonymous with American values, while under others, it has emphasized the superiority of American values over international standards."33 According to his analysis, therefore, American exceptionalism encompasses at least three elements: Exemptionalism, double standards, and legal isolationism. ${ }^{34}$ In the context of this Article, it is worth noting in particular, that the dimension of the so-called legal isolationism expresses the democratic concerns of some American constitutional law scholars about the use of foreign law in the interpretation of the U.S. Constitution. The alleged phenomenon that "American judges are exceptionally resistant to using foreign human rights precedents to guide them in their domestic opinions" 35 results not merely from the presupposition that American constitutionalism "regards constitutional law as the embodiment of a particular nation's democratically self-given legal and political commitments," 36 but also, and particularly, from the belief that "[t]he U.S. Constitution differed in one fundamental respect from any democratic constitution that any large state had ever had: It was enacted through a process of popular deliberation and consent." 37 Furthermore, to the extent that "[t]he United States has a vigorous, and successful method for human rights protection," 38 the American Constitution reflects not only the democratic self-determination of the American people, but also the admirable achievement of democracy in America. As John O. McGinnis observes:

Jekyll-and-Hyde Exceptionalism]; Frank I. Michelman, Integrity-Anxiety?, in AMERICAN EXCEPTIONALISM AND HUMAN Rights 241 (Michal Ignatieff ed., 2005); Andrew Moravcsik, The Paradox of U.S. Human Rights Policy, in AmERICAN Exceptionalism and Human Rights 147 (Michal Ignatieff ed., 2005); Steven G. Calabresi, A Shining City on a Hill: American Exceptionalism and the Supreme Court's Practice of Relying on Foreign Law, 86 B.U. L. REV. 1335 (2006). See also Mark C. Rahdert, Exceptionalism Unbound: Appraising American Resistance to Foreign Law, 65 CATH. U. L. REV. 537, 547-49, 563-602 (2015-2016) (examining the idea of American exceptionalism in the specific context of "the recent wave of state ['Anti-Foreign-or-International-Law' statutes and proposals]" and arguing for "selective" rather than "wholesale" exceptionalism). For a comparison between American and Australian idea of exceptionalism, see Mark Tushnet, The Inevitable Globalization of Constitutional Law, 49 VA. J. INT'L L. 985, 986 (2008-2009); Michael Kirby, Constitutional Law and International Law: National Exceptionalism and the Democratic Deficit, 98 GEO. L.J. 433, 451-58 (2009-2010).

${ }^{32}$ In particular, American exceptionalism puts specific emphasis on the contrast between American and European traditions. See Calabresi, supra note 31, at 1398 ("The whole point of being Americans for many of us is that we are not Europeans; we are a special people, in a special land, with a special mission.”).

${ }^{33}$ Michael Ignatieff, Introduction: American Exceptionalism and Human Rights, in AMERICAN EXCEPTIONALISM AND Human Rights 1, 1 (Michal Ignatieff ed., 2005).

${ }^{34}$ See id. at 3-9. See also Koh, On American Exceptionalism, supra note 31, at 1482-87.

${ }^{35}$ Ignatieff, supra note 33 , at 9 . According to Ignatieff s observation, the American legal isolationism is also reflected in the phenomenon that "the trade in legal understanding continues to be mostly one-way, with the U.S. legal tradition teaching others but not learning much itself." Ignatieff, supra note 33, at 9. It is worth noting, though, that the U.S. Supreme Court did refer to foreign law in light of its constitutional interpretation in a number of cases. See, e.g., JULIAN KU \& JOHN YoO, TAMING Globalization: International LAw, the U.S. Constitution, AND the New World Order 227 (2012) (arguing that "the turn to foreign and international law has recently been adopted by majorities of the Supreme Court"); Sujit Choudhry, Migration as a New Metaphor in Comparative Constitutional Law, in The MigRation of Constitutional IDEAs 1,2 (Sujit Choudhry ed., 2006) (maintaining that Justices advocating the migration of constitutional ideas "appear to have gained the upper hand").

${ }^{36} J$ Jed Rubenfeld, Unilateralism and Constitutionalism, 79 N.Y.U. L. REv. 1971, 1994 (2004). See also Antonin Scalia \& Stephen Breyer, A Conversation Between U.S. Supreme Court Justices: The Relevance of Foreign Legal Materials in U.S. Constitutional Cases: A Conversation Between Justice Antonin Scalia and Justice Stephen Breyer, 3 INT'L J. CoNST. L. 519, 521 (2005).

${ }^{37}$ Jed Rubenfeld, The Two World Orders, in EuropeAn AND US Constitutionalism 280, 287 (Georg Nolte ed., 2005).

${ }^{38}$ Jack Goldsmith, Should International Human Rights Law Trump US Domestic Law?, 1 CHI. J. INT'L. L. 327,335 (2000) (arguing that "a flourishing constitutional democracy with a powerful tradition of domestic human rights protection... [highly debated issues such as]...homosexuality, immigration, age, hate speech, family structure and genetics... should not be decided by international norms and institutions"). 
Zimbabwe has a different approach to law and so does China, but in the end one may have doubts that they will add much to the stock of useful information and experimentation. But the history of the United States suggests that from the revolution onward it has pursued unique or unusual approaches that later command broad consensus and improve the world's welfare. The United States has one of the first written constitutions. Other nations followed. The United States has historically had one of the most deregulated market economies: it consistently delivered some of the highest sustained growth rates in the developed world and has reached one of the highest standards of living. The United States has governmental mechanisms that allow for swift and efficient war-making capacities. It thus rescued the world from totalitarian nightmares. In the sphere of human rights, the United States originated written protections for free speech and continues to have one of the broadest charters for free expressions in the world. ${ }^{39}$

In the sense that American democracy has been exceptionally successful in comparison internationally, therefore, critics of an "internationalist approach" in interpreting the U.S. Constitution warn that "[o]ver-reliance on foreign precedents conflicts with the structure and history of our own Constitution." 40 In particular, "[t]here is no indication that the American people today believe that their constitutional rights and delegations of powers should be interpreted in light of foreign jurisdictions. In fact, American attitudes toward international human rights indicate the opposite." ${ }^{11}$ In short, for those who stress the special character of American experience, interpreting the Constitution of the United States under the guidance or influence of foreign law would undermine popular sovereignty precisely because it enables alien law to decide how the American Constitution should be understood, and in this way supersede the democratic will of the American people.

To be sure, because opinions with regard to the legitimacy or appropriateness of using foreign resources in constitutional interpretation are divided in the United States, ${ }^{42}$ American exceptionalism does not at all represent the consensus opinion of the American constitutional law scholars with regard to foreign law. ${ }^{43}$ Nevertheless, in comparison with the situation in Germany, the idea

\footnotetext{
${ }^{39}$ John O. McGinnis, Foreign to Our Constitution, 100 Nw. U. L. REv. 303, 318-19 (2006). For the unique advantage of the U.S. constitutional law based on American exceptionalism, see also Eric A. Posner \& Cass R. Sunstein, The Law of Other States, 59 STAN. L. REV. 131, 139 (2006).

${ }^{40} \mathrm{~J}$. Harvie III Wilkinson, The Use of International Law in Judicial Decisions, 27 HaRV. J.L. \& PUB. Pol’y 423, 427 (20032004).

${ }^{41} \mathrm{KU} \&$ YoO, supra note 35 , at 242.

${ }^{42}$ Over the past decade, the question of whether or not the U.S. Supreme Court should rely on foreign law to guide their interpretation of the Constitution has constantly been discussed and debated. For an overview of the debates in scholarship and practice, see, e.g., Parrish, supra note 1, at 638-52; Ku \& Yoo, supra note 35, at 4-10; ErIC A. Posner, The PeriLs of Global Legalism 100-25 (2009); Roger P. Alford, Four Mistakes in the Debate on Outsourcing Authority, 69 ALB. L. REV. 653, 656-64 (2006); Mark Tushnet, Transnational/Domestic Constitutional Law, 37 LoY. L. A. L. ReV. 239, 241-67 (2003); Mark Tushnet, Referring to Foreign Law in Constitutional Interpretation: An Episode in the Culture Wars, 35 U. BALT. L. REv. 299, 300-09 (2006); Daniel A. Farber, The Supreme Court, the Law of Nations, and Citations of Foreign Law: The Lessons of History, 95 CAL. L. REv. 1335, 1340-44 (2007); T. Alexander Aleinikoff, Thinking outside the Sovereignty Box: Transnational Law and the U.S. Constitution, 82 TEX. L. REV. 1989, 1992-2004 (2004); Sitaraman, supra note 1, at 654-64; JEREMY WALDRON, "Partly Laws Common to All Mankind": Foreign LaW in American Courts 142-70 (2012).

${ }^{43}$ In fact, not all of those who warn of the democratic costs of the reference to foreign law explicitly emphasize the uniqueness of American democracy. For example, some critics simply assert that, as a demonstration of democratic popular will, the domestic constitutional guarantees "are not to be interpreted to give expression to international majoritarian values to protect the individual from democratic governance.” Roger P. Alford, Misusing International Sources to Interpret the Constitution, 98 AM. J. INT'L L. 57, 59 (2004). See also McGinnis, supra note 39, at 319 (warning that, in allowing foreign law to guide the interpretation of the Constitution, "[c]itizens who cannot succeed in the domestic political process can go abroad to influence our laws through the backdoor"). Still, these democratic critiques of the reliance on foreign law reflect viewpoints that are very different from those advanced by most German scholars. One of the most remarkable differences is that while the German mainstream straightforwardly recognizes the normative character of international law, many American discussions tend to
} 
of American exceptionalism does demonstrate the characteristics of its conception of democracy. For those who believe in the uniqueness and superiority of American experiences and values, the interpretation of the U.S. Constitution should not take foreign law into consideration. This is because not only is the Constitution an expression of democratic will of the American people, but also, and particularly, American constitutional democracy is so different and extraordinarily successful that it cannot be guided by any foreign norms and institutions. As Rubenfeld states, " $[\mathrm{t}]$ he rest of the world needed American law and American-modeled constitutions, but we didn't. The rest of the world might not be able to trust its own democratic self-government, but we could." ${ }^{4}$ Accordingly, it is argued that American democracy is to be distinguished from the European democratic tradition because in searching for universal rights and values, Europeans tend to regard constitutionalism as a tool for constraining democracy. ${ }^{45}$ For example, Kenneth Anderson argues that, especially after 1945, European constitutionalism has developed "a tradition deeply fearful of democracy and above all hostile to the concept of popular sovereignty." 46 By contrast, Americans tend to trust democratic self-government and popular sovereignty rather than to develop universal human rights and principles to be imposed upon democracy. ${ }^{47}$ Indeed, in the American view, human rights themselves are to be understood as "products of democracy." Moreover, as McGinnis states, "the United States has a structure of federalism and more general traditions of decentralization that are important processes for testing the content of rights." 48 Rubenfeld thus argues that "[f] or Americans, a democratic nation's constitutional law is supposed to reflect that nation's fundamental legal and political commitments." ${ }^{\prime 9} \mathrm{He}$ even maintains that " $[\mathrm{t}]$ he US Constitution did not speak in the language of universal rights. It spoke in the language of popular sovereignty." ${ }^{0}$ Viewed this way, using foreign law in interpreting the U.S. Constitution becomes even more problematic because it attempts to impose universal values and principles that are developed outside the United States on the constitutional democracy of the U.S., which has never embraced the idea that universal human rights transcend national democratic politics. Precisely in comparison with the German discussions and critiques of an overreliance on international law, therefore, the American democratic arguments against the use of foreign law in constitutional interpretation are remarkably characteristic of their criticism under

regard foreign law merely as the majoritarian preferences of another country, or of the entire international community, and particularly in this sense reinforce the idea that the American Constitution should not be interpreted according to the majoritarian views of the other nation(s). See, e.g., Ernest A. Young, Foreign Law and the Denominator Problem, 119 HARV. L. REV. 148, 154, 163 (2005) (describing international law as "world opinion"); Vlad F. Perju, The Puzzling Parameters of the Foreign Law Debate, 2007 UTAH L. ReV. 167, 175-76, 196 (2007) (criticizing the "internationalists" for their focus on "situations where there is a world consensus"); Wilkinson, supra note 40, at 426 (maintaining that, when judges rely on foreign sources, they create the perception that "foreign sentiment shapes domestic law"). It is primarily such a political understanding of foreign law that leads to the notion of the so-called "international counter-majoritarian difficulty" of the U.S. Supreme Court, which again demonstrates a clear contrast to the democratic arguments in Germany. For the international counter-majoritarian difficulty, see Roger P. Alford, Misusing International Sources to Interpret the Constitution, 98 AM. J. INT'L L. 57, 59 (2004). See also infra note 63, for further discussion of the international counter-majoritarian difficulty as an expression of American distinctiveness in response to the Supreme Court's use of foreign law in interpreting the Constitution.

${ }^{44}$ Rubenfeld, supra note 36 , at 1989.

${ }^{45}$ See also McGinnis, supra note 39, at 311 ("European traditions are more favorable to the imposition of elite moral views. Indeed, the European notion of human rights is the product of a search for eternal normative truths to be imposed against democracy.").

${ }^{46}$ Kenneth Anderson, Foreign Law and the U.S. Constitution, 131 Pol’y Rev. 33, 47-48 (2005).

${ }^{47}$ See, e.g., POSNER, supra note 42, at 227 (“Americans simply do not share Europeans' fears about democracy; in the United States, the people remain the source of all political authority as a matter of public discourse.”).

${ }^{48}$ McGinnis, supra note 39, at 312. See also John O. McGinnis, Contemporary Foreign and International Law in Constitutional Construction, 69 Alb. L. Rev. 801, 806-07 (2006); Wilkinson, supra note 40, at 427.

${ }^{49}$ Rubenfeld, supra note 37 , at 289.

${ }^{50}$ Rubenfeld, supra note 37, at 287. See also Paul W. Kahn, American Exceptionalism, Popular Sovereignty, and the Rule of Law, in American Exceptionalism and Human Rights 198, 206-07 (Michal Ignatieff ed., 2005); Richard A. Posner, A Political Court, 119 Harv. L. Rev. 32, 84-89 (2005). 
the influence of American exceptionalism. As analyzed before, although German mainstream opinion constantly adheres to a dualistic construction of the relationship between international and domestic law and thereby regards international law as external law, none of the democratic concerns in Germany have been based upon the belief of the uniqueness of the German constitutional democracy. Accordingly, this explains the assertion that the development of German constitutional law should by no means be affected by alien views. By contrast, as already shown above, a number of those who oppose the use of foreign law in American constitutional interpretation tend to underline the distinctiveness and incomparability of American constitutionalism. To this extent, the apparently widespread concerns about foreign law in the United States can only be explained with reference to the legacy of American exceptionalism.

It is thus worth noting in the present context, that the significance of such an exceptionalist view for the development of American constitutional law should not be undervalued. While the term "American exceptionalism" does not always appear in arguments against the use of foreign law, discussions highlighting the exceptional success of American constitutionalism and the contrast between "foreign law" and "our law" are to be traced back to the implicit influence of American exceptionalism. ${ }^{51}$ As Eric A. Posner and Cass R. Sunstein emphatically argue:

Consideration of foreign law implicitly denies American exceptionalism and everything that accompanies it - national pride, celebration of the founding, the notion that America has a distinctive and unique mission, and so forth. Use of foreign law implicitly treats America as merely one nation among others, rather than as a shining city on the hill that serves as a model for other nations. On this view, the United States should be a leader, not a follower, and use of foreign precedents turns the nation into a follower. Worst of all, the practice encourages judges to express humility toward foreigners rather than to the founding document and those who ratified it. ${ }^{52}$

Thus conceived, whereas American exceptionalism by no means qualifies as the majority opinion with regard to the use of foreign law in constitutional interpretation, the underlying idea that America is far more than "merely one nation among others" appears to be widely accepted by Americans. It is thus no surprise that, as "commonly understood by American jurists," American constitutional law is "root-and-branch domestic law."

\section{The Impenetrable American Constitution}

It follows from the alleged contrast between the European and the American conceptions of constitutionalism and democracy that - at least for those who adhere to American exceptionalismAmerican constitutional law should not only resist any attempts to interfere with the democratic governance of the United States, but, in particular, prevent itself from being "rewritten" by any non-American legal norms and developments. From this perspective, it is not at all surprising that most American exceptionalists are not interested in discussing the legitimacy or appropriateness of the resort to foreign law based on a careful distinction among the various ways that foreign law is used in constitutional interpretation, but rather simply reject foreign law as a whole. ${ }^{54}$ Nor do they care about the different types of foreign law or the different theoretical approaches between

\footnotetext{
${ }^{51}$ Indeed, even those who encourage translational judicial dialogue do not always ignore the significant influences of American exceptionalism. See, e.g., Michelman, supra note 31, at 242-43, 273-76. Some of them even argue that the transnational legal process helps promote positive aspects of American exceptionalism. See, e.g., Koh, America's Jekyll-and-Hyde Exceptionalism, supra note 31, at 130-43.

${ }^{52}$ Posner \& Sunstein, supra note 39 , at 139.

${ }^{53}$ Michelman, supra note 31 , at 243.

${ }^{54}$ For a similar observation, see Sitaraman, supra note 1 , at $655-56$.
} 
monism and dualism in inquiring into the relationship between international and domestic law. ${ }^{55}$ For the exceptionalists, after all, what really matters is not how, or to what extent foreign law could be incorporated into the American constitutional order, but whether the content of the U.S. Constitution is truly determined by the American people themselves, "free from the views of other nations or the international community." ${ }^{56}$ From the exceptionalist view, therefore, because the U.S. Constitution is the product of American democracy - which is unique in the sense that it serves as a model for the international community-there is no reason that its interpretation should refer to any non-American values or principles. To put it simply, according to American exceptionalism, the U.S. Constitution is democratic, purely American, antiuniversalistic, and therefore not only superior to, but also impenetrable by, foreign law. As Antonin Scalia puts it: 'Irrelevant are the practices of the 'world community,' whose notions of justice are (thankfully) not always those of our people." 57

Precisely in view of this impenetrability, the point of constitutional interpretation is to defend the U.S. Constitution against foreign intervention, not to reshape it according to the preferences, or even political motivations, of the Supreme Court Justices. It is thus not surprising that the Supreme Court has been sharply criticized for resorting to foreign law in a selective and arbitrary manner, ${ }^{58}$ even though in most cases the foreign resources cited only serve an informative function. ${ }^{59}$ Unlike the situation in Germany-where the Federal Constitutional Court is usually expected to be the most important guardian of German democracy in external relations ${ }^{60}$ American critics have warned again and again that allowing the Supreme Court to cite foreign law in interpreting the U.S. Constitution not only inappropriately enhances judicial power, ${ }^{61}$

\footnotetext{
${ }^{55}$ See also Matthias Kumm, Democratic Constitutionalism Encounters International Law: Terms of Engagement, in THE Migration of Constitutional Ideas 256, 279 (Sujit Choudhry ed., 2006); Rex D. Glensy, The Use of International Law in U.S. Constitutional Adjudication, 25 EMORY INT'L L. Rev. 197, 199-200 (2011). To be sure, some American critics of relying on foreign law in constitutional interpretation are actually fully aware of the different effects of different types of foreign and international law in the U.S. legal system. See, e.g., Anderson, supra note 46, at 34; Posner \& Sunstein, supra note 39, at 165. Nevertheless, many of these critics still put emphasis on the notion that both domestic law of foreign states and international law are to be equally categorized as non-American laws that differ qualitatively from American law. In particular, it is emphasized that even international treaties to which the United States is a party to do not necessarily have a binding force on American (constitutional) law, because the United States usually ratifies a treaty with significant reservation or deems a ratified treaty to be non-self-executing. See, e.g., McGinnis, supra note 39, at 311-18; Goldsmith, supra note 38, at 328-31; Ku \& Yoo, supra note 35, at 242-45; Robert J. Delahunty \& John Yoo, Against Foreign Law, 29 HarV. J.L. \& PuB. Pol’y 291, 311-12 (2005). From this point of view, the contrast between German and American discussions in treating different types of foreign law comes not merely from the textual differences between the German Basic Law and the U.S. Constitution. In other words, the absence of comparable provisions regarding the commitment to international cooperation or integration in the U.S. Constitution alone can hardly explain the exceptionalist view on foreign law as a whole. Rather, as illustrated, American exceptionalism is characteristic of its ideological adherence to the uniqueness of the United States and its constitutional democracy, and accordingly of its antagonism against any non-American products.

${ }^{56} \mathrm{KU} \&$ Yoo, supra note 35, at 252 ("Popular sovereignty requires that the Supreme Court and the other branches of government interpret the nation's founding law for themselves, free from the views of other nations or the international community.").

${ }^{57}$ Atkins v. Virginia, 536 U.S. 304, 347-48 (2002) (Rehnquist, J., dissenting).

${ }^{58}$ See, e.g., Roper v. Simmons, 543 U.S. 551, 627 (2005) (Scalia, J., dissenting) (“To invoke alien law when it agrees with one's own thinking, and ignore it otherwise, is not reasoned decisionmaking, but sophistry."). For similar criticism, see Wilkinson, supra note 40 , at 428 ; Posner, supra note 50 , at $84-89$.

${ }^{59}$ See also Sitaraman, supra note 1, at 664-91; Kumm, supra note 55, at 278-79; Parrish, supra note 1, at 661, 670; Scalia \& Breyer, supra note 36, at 524. But see KU \& Yoo, supra note 35, at 228-31 (arguing that "use of foreign decisions extends beyond mere ornamentation").

${ }^{60}$ See, e.g., GRIMM, supra note 30, at 151-52; Huber, supra note 30, at 126-27. It is to be noted that, while the development of the Federal Constitutional Court of Germany and its case law has been widely recognized as a success story in comparison internationally, German scholars have rarely argued that the jurisprudence of their Constitutional Court should be followed by courts of other nations or adopted by international courts, even though it actually serves as a model for many national or international courts in the world.

${ }^{61}$ See, e.g., Goldsmith, supra note 38 , at 332-33; Wilkinson, supra note 40, at 426; Ku \& Yoo, supra note 35, at 240-41; Posner, supra note 50, at 86.
} 
but in this way inevitably threatens democracy in America, because the democratic discourse and governance is reserved exclusively to the American people, not foreigners. ${ }^{62}$ Observed this way, the democratic concerns about judicial arbitrariness in choosing and using foreign law result not so much from the so-called "counter-majoritarian difficulty" of the Supreme Court. ${ }^{63}$ Rather, to the extent that, as a court under the common-law tradition, the U.S. Supreme Court has always played the central role in shaping and developing American constitutional law and democracy, ${ }^{64}$ the democratic concerns expressed by those who believe in American exceptionalism stem mainly from the fear that the Supreme Court would become even more powerful through "deAmericanizing" the American Constitution.

\section{Foreign Law as a Danger to Constitutional Democracy? A Critical Comparative Analysis}

\section{Different Conceptions of Democracy in Germany and the United States}

The foregoing analysis has clarified that the democratic arguments advanced in Germany and the United States are actually based on different understandings of democracy. In other words, in saying that the effect of foreign law on the domestic constitutional order should be constrained for democratic reasons in particular, German and American critics tend to focus on different

\footnotetext{
${ }^{62}$ See Alford, supra note 43, at 60 ("[T] he global consensus does not provide content to the national consensus and the global consensus is of no relevance in the absence of a national consensus.”); McGinnis, supra note 48, at 806-07: Particularly, if one believes in American exceptionalism, one will think it a loss to the entire world to have our distinctive norms prematurely extinguished through the operation of a constitutional law construed along the lines of international and foreign law... It suddenly gives people in other nations some ability to affect the shape of our polity.

Posner, supra note 50, at 88 ("Judges in foreign countries do not have the slightest democratic legitimacy in a U.S. context.").

${ }^{63}$ For the counter-majoritarian difficulty of the U.S. Supreme Court, see generally ALEXANDER M. BICKEL, THE LEAST Dangerous Branch: The Supreme Court at the Bar of Politics 23 (2d ed. 1986) (stating that "[t]he root difficulty is that judicial review is a counter-majoritarian force in our system”). For the counter-majoritarian difficulty of judicial review as a major concern of the American constitutional scholars, see generally Barry Friedman, The History of the Countermajoritarian Difficulty, Part One: The Road to Judicial Supremacy, 73 N.Y.U. L. Rev. 333 (1998); Kenneth Ward, The Counter-Majoritarian Difficulty and Legal Realist Perspectives of Law: The Place of Law in Contemporary Constitutional Theory, 18 J.L. \& PoL. 851 (2002); Mark A. Graber, Foreword: From the Countermajoritarian Difficulty to Juristocracy and the Political Construction of Judicial Power, 65 MD. L. REv. 1, 1-6 (2006). As is well known, many, if not most, scholars in the United States have shared the opinion that the Supreme Court inevitably lacks democratic legitimacy that is comparable with the legislators. In this respect, the Supreme Court's role as a counter-majoritarian check on majoritarian democracy seems especially problematic when its judicial review is based on reference to foreign law, which by no means represents the majoritarian views of the United States. Precisely within this context, Roger P. Alford maintains that, in resorting to foreign law, the U.S. Supreme Court suffers from an "international counter-majoritarian difficulty." Alford, supra note 43, at 59:
}

The difficulty for international majoritarians is that, while certain constitutional provisions have been interpreted to embrace community standards, those standards have been interpreted consistently with - not counter to - majoritarian values reflected in our national experience. The countermajoritarian difficulty would suggest that international norms cannot be internalized within our Constitution unless such norms are first internalized by our people as our community standards. That is, international standards cannot serve as community standards unless they reflect our own national experience. To conclude otherwise would grant countermajoritarian international norms constitutional relevance as a community standard.

${ }^{64}$ While it is generally accepted that the U.S. Supreme Court has always been confronted with the counter-majoritarian difficulty, it should not be neglected that the Supreme Court is also characteristic of its common law tradition, which highlights the significant role of the judiciary and thus is unlikely to regard the courts merely as "the weakest," or "the least dangerous" branch. For the influence of the American common law tradition on the status of the U.S. Supreme Court in the American constitutional system, see Shu-Perng Hwang, The Supreme Court in a Common Law Tradition: The Democratic Legitimacy of Judicial Review in Light of American Legal Realism, 35 COMM. L. WorLd Rev. 216, 221-25 (2006). For the political role of the U.S. Supreme Court, see Kahn, supra note 50, at 206-07 (arguing that, compared with the situation of other nations whose constitutionalism is a matter of "the elaboration of an abstract logic of rights ... American legal scholars ... are quite comfortable speaking of the political role of the courts ... [t] he legitimacy of the Court is located not in the 'science of law' but in politics"). 
aspects of democracy, and therefore express different democracy-related concerns. As discussed above, the German mainstream opinion insists that democracy can only be realized and safeguarded within the state, and in particular, by the national constitutional order. Therefore, in order to prevent the erosion of democracy through the irresistible trend of Europeanization, or to find a balance between European integration and democratic control, what is crucial is to defend the constitutional identity of the German Basic Law especially through adherence to its absolute supremacy over any foreign law, including European Union law. By contrast, those Americans who believe in American exceptionalism refer to democracy not merely because they insist on the inviolable role of the state and the domestic constitutional order in realizing democracy, but particularly because they think democracy in America is so unique that it is incomparable with any other democratic traditions and experiences. It is thus quite reasonable to assert that-while other national constitutional systems may have to adjust themselves to internationalization and globalization-American constitutional law is entitled to reject any explicit or implicit intrusion of non-American resources. ${ }^{65}$ Observed this way, it can be said that while the German critics adhere to the inseparable relationship between democracy and state, the American critics tend to emphasize the inseparable relationship between democracy and America. For the German constitutional order, therefore, the democratic baseline is that the constitutional identity must remain untouched. In the context of the U.S. constitutional system, however, the question is not how foreign law could be incorporated into American constitutional law, but whether foreign law should ever be taken into account in light of constitutional interpretation.

The observation that German and American critics embrace different conceptions of democracy in defending the respective constitutional orders may help explain why the German and the American democratic arguments tend to misunderstand each other to a certain degree. On the one hand, as mentioned before, some American scholars emphatically assert the fundamental difference between European and American constitutional traditions, arguing that Europeans today have developed "a tradition deeply fearful of democracy and above all hostile to the concept of popular sovereignty." 66 In their view, so-called European democracy is "less democratic than the American democracy" not merely because the post-war Europeans "were ready to embrace an antinationalist, antidemocratic international legal system," 67 but more deeply because the continental European democracies are characteristic of "their monarchical histories, their lingering aristocratic cultures, and their tendency to favour centralised, bureaucratic governance." 68 Thus, it is even argued that Europeans, obsessed with abstract, universal rights and principles, are in general "tolerant" of the European Union's democratic deficit. ${ }^{69}$ While such a viewpoint may intend to exaggerate the contrast between Europe and America so as to highlight the uniqueness of American constitutionalism, it apparently fails to notice the theoretical, as well as practical, developments in German constitutional law. As illustrated before, the German discussions are always preoccupied with a dualistic view on the relationship between international and domestic law, and thereby tend to emphasize the indispensable role of the states in safeguarding popular sovereignty and constitutional democracy. Therefore, especially in the context of external relations, German mainstream opinion has never overlooked the significance of democracy and self-governance. To the contrary, democracy remains a key argument against an unconstrained Europeanization both in scholarship and practice. As shown above, it is precisely the Federal Constitutional Court of Germany that refers not only to the close relationship between national sovereignty and democracy, but to the substantial democratic limits on European integration, as

\footnotetext{
${ }^{65}$ See, e.g., Rubenfeld, supra note 36, at 1974-75 (“American constitutionalism differs in certain fundamental respects from contemporary European constitutionalism, and the distinctive features of American constitutionalism have implications not only for the 'jus cogens' or 'customary international law,' but for supranational legal institutions as a whole.").

${ }^{66}$ Anderson, supra note 46 , at $47-48$.

${ }^{67}$ Rubenfeld, supra note 36 , at 1974 .

${ }^{68}$ Rubenfeld, supra note 37 , at 289.

${ }^{69}$ Rubenfeld, supra note 37 , at 289.
} 
well as the absolute supremacy of the Basic Law in defending German democracy. ${ }^{70}$ Viewed this way, the comments of some American observers on European and German constitutional traditions are not merely superficial and misleading. Rather, they obviously ignore the crucial role played by the democratic arguments of the German Constitutional Court and constitutional law scholars in contemporary discussions in German constitutional law. From a comparative perspective, such a huge, fundamental misunderstanding may result from the fact that, as was suggested, those who believe in American exceptionalism understand democracy in a purely American way. To the extent that only American democracy qualifies as a real democracy, the democratic arguments advanced in Germany-however skeptical towards Europeanization and internationalization - are inevitably less democratic.

On the other hand, it seems that the characteristics of the democratic arguments advanced by American exceptionalists have received insufficient attention in some German or European discussions as well. To be sure, the idea of American exceptionalism is not at all unfamiliar to German scholars. ${ }^{71}$ Nevertheless, the exceptionalist rejection of the use of any foreign law in light of the interpretation of the U.S. Constitution is usually understood as a typical response to the counter-majoritarian dilemma of the U.S. Supreme Court. To put it concretely, in the sense that the U.S. debates on the democratic legitimacy of judicial review have, admittedly, been dominated by discussions relating to the counter-majoritarian difficulty of judicial review, some European commentators tend to regard the exceptionalist critique of the Supreme Court's reference to foreign law as a democratic, counter-majoritarian difficulty-related concern about the overexpansion of judicial discretion. ${ }^{72}$ Moreover, it has been pointed out that the exceptionalist critique reflects concerns about the democratic deficit of the decision-making process of international law, whereby democracy is referred to as self-determination and self-governance of nation-states. ${ }^{73}$ From the perspective of American exceptionalism, though, the references both to the countermajoritarian difficulty of the Supreme Court and to the democratic deficit of international law show that these European commentators neglect one important dimension of the exceptionalist conception of democracy: An exceptionalist insistence on the uniqueness and pureness of American democracy, and thereby an exceptionalist identification of democracy with American constitutional traditions. As illustrated before, such a conception of democracy is to be distinguished from the German conception of democracy, because it puts emphasis not merely on the inviolable role of the state in realizing and safeguarding democracy, but more radically on the unique, exceptional impenetrability of the U.S. Constitution. ${ }^{74}$ Viewed this way, the exceptionalist critique of the use of foreign law in constitutional interpretation results less from the concern about the counter-majoritarian difficulty of the Supreme Court than from the belief that all American decision-making processes, including judicial review, should be free from foreign control and influence. In other words, the exceptionalists have criticized the U.S. Supreme Court for its reliance on foreign law, not because they think the Supreme Court should remain as a nonpolitical branch that has nothing to do with democratic decision-making, but because they think that-as an expression of American democracy ${ }^{75}$ - the constitutional interpretation of the Supreme Court should only reflect the will of the American people, and thus must reject any interpretative tools that are non-American.

\footnotetext{
${ }^{70}$ See discussion supra Part B.

${ }^{71}$ See, e.g., Heike Krieger, Die Herrschaft der Fremden - Zur demokratietheoretischen Kritik des Völkerrechts, 133 ARCHIV DES ÖFFENTLICHEN RECHTS 315, 320-23 (2008).

${ }^{72}$ See, e.g., Krieger, supra note 71, at 322; Andrea Bianchi, International Law and US Courts: The Myth of Lohengrin Revisited, 15 EUR. J. INT'L L. 751, 775-76 (2004).

${ }^{73}$ See, e.g., Krieger, supra note 71, at 322-23; Armin von Bogdandy, Comment on Jed Rubenfeld, The Two World Orders, in European and US Constitutionalism 297, 297-98 (Georg Nolte ed., 2005).

${ }^{74}$ See discussion supra Part C.II.

${ }^{75}$ See also Choudhry, supra note 35, at 6 ("To Americans, judicial review is legitimate because they view 'the Court as the voice of the Sovereign People."”).
} 


\section{One Common Myth}

While German and American democratic arguments in the context of the relationship between foreign law and domestic constitutional law stem from different understandings of democracy, they both presuppose a state-centered conception of democracy and of the international legal order. On the one hand, both the German insistence on the inviolable constitutional identity and supremacy of the German Basic Law over international — as well as supranational and foreign law-and the American belief in the uniqueness and therefore impenetrability of the American Constitution adhere to the standpoint that, in light of international relations, the primary function of democracy is to protect the self-determination of the states. In this regard, both the German and the American democratic arguments share the presupposition that real democracy can only exist within the state. Accordingly, the self-determination of the individual must be premised upon the self-determination of the state, which thus should always play the decisive role in the international legal order precisely on democratic grounds. ${ }^{76}$ On the other hand, both the German and the American democratic concerns about the excessive intrusion of foreign law, and especially of international law, are based on the presupposition that the expansion of international law threatens to undermine democracy to the extent that in building up a transnational, universal legal system, it aims at the establishment of a substantially uniform legal order. ${ }^{77}$ This inevitably ignores the diversity of different domestic legal traditions and accordingly runs counter to the democratic requirement that the states' self-determination must remain intact. Therefore, it is no surprise that many German constitutional law scholars constantly emphasize the heterogeneity between domestic law and international or transnational law, and therefore reject a hierarchical view on the legal system of the European Union with the priority of European Union law over domestic law. From the perspective of a state-centered conception, such a hierarchical view would inevitably imply the recognition of a new hierarchy of norms that is ready to replace the respective selfdetermination of domestic constitutional orders with a set of uniform, homogeneous rules. Moreover, as suggested before, those who embrace the idea of American exceptionalism even condemn the so-called internationalist approaches in favor of the development of global and comparative constitutionalism. ${ }^{78}$ For them, American democracy means the self-determination of the American people. Therefore, as an expression of American democracy, American constitutional law should consist only of elements that are truly American. In this regard, even a transnational constitutional dialogue would become problematic in the sense that-in searching for universal principles and values - it allows foreign viewpoints and experiences to affect the development of American constitutional law and American democracy. ${ }^{79}$

\footnotetext{
${ }^{76}$ See, e.g., Sebastian Müller-Franken, Die demokratische Legitimation öffentlicher Gewalt in den Zeiten der Globalisierung: Zur unhintergehbaren Rolle des Staates in einer durch Europäisierung und Internationalisierung veränderten Welt, 134 ARCHIV DES ÖFFENTLICHEN ReChTS 542, 557-58 (2009); DieTER GRIMM, Die Rolle der nationalen Parlamente in der Europäischen Union, in EUROPA JA - ABER Welches?: Zur VerfasSUNG DER EUROPÄISCHEN DEMOKRATIE 183, 189-90 (2d ed. 2016); Isensee, supra note 15, at 265-69; Rubenfeld, supra note 37, at 288-89; McGinnis, supra note 48, at 805-06.

${ }^{77}$ See, e.g., Dieter Grimm, Der Datenschutz vor einer Neuorientierung, 68 JURISTEN ZeITUNG 585, 591-92 (2013); Peter M. Huber, Unitarisierung durch Gemeinschaftsgrundrechte - Zur Überprüfungsbedürftigkeit der ERT-Rechtsprechung, 43 EUROPARECHT 190, 194-95 (2008); Rubenfeld, supra note 36, at 1993-2006; Posner, supra note 50, at 85-87; Roger P. Alford, In Search of a Theory for Constitutional Comparativism, 52 UCLA L. REv. 639, 707 (2004-2005).

${ }^{78}$ For the rise of global and comparative constitutionalism and its constructive implication for the interpretation of the U.S. Constitution, see, e.g., David S. Law, Generic Constitutional Law, 89 MINN. L. Rev. 652 (2004-2005); Mark Tushnet, Some Reflections on Method in Comparative Constitutional Law, in The Migration of Constitutional IDEAS 67, 67-83 (Sujit Choudhry ed., 2006); Melissa A. Waters, Mediating Norms and Identity: The Role of Transnational Judicial Dialogue in Creating and Enforcing International Law, 93 GEO. L.J. 487 (2005); Mary Ann Glendon, Comparative Law in the Age of Globalization, 52 DuQ. L. Rev. 1, 3-21 (2014); Anne-Marie Slaughter, A New World Order 65-103 (2004); Glensy, supra note 55 , at 201-35, 248-66.

${ }^{79}$ See, e.g., Posner, supra note 50, at 84-89; Alford, supra note 77, at 709-10.
} 
It follows from the foregoing analysis that the state-centered conception shared by the German and the American democratic arguments adheres to the contrast between domestic law and foreign law. While the former stands for popular sovereignty and democratic self-determination, the latter refers to something external and-when it comes to international law-something that aims at uniformity and homogeneity. To this extent, foreign law-international law in particular-is vulnerable not only because it is anti-democratic, but because it is anti-pluralistic. Therefore, in response to the irresistible trends towards Europeanization and internationalization, what is crucial is not to find a substantial harmony between foreign law and domestic constitutional law, but rather to defend the domestic constitutional order from being relativized or eroded. Such a statecentered and thereby solipsistic view on the relationship between foreign law and domestic law, ${ }^{80}$ however, inevitably leads to contradictions inherent in the respective democratic arguments of Germany and the United States. With regard to German discussions, the insistence on the absolute supremacy of the German Constitution contradicts the principle of openness towards international law and European Union law in the sense that it simply excludes the possibility of substantial harmonization or convergence through transnational judicial dialogues when a collision of norms between international law and domestic constitutional law occurs. ${ }^{81}$ As far as American exceptionalism is concerned, the contradiction lies in the fact that the adherence to the impenetrability of the American Constitution hardly corresponds to the principle of pluralism underlying American democracy. ${ }^{82}$ These contradictions encountered in both countries reflect that while German and American democratic arguments seem to think highly of the liberal and pluralistic dimensions of democracy, their attitudes toward foreign law are far from openminded. The underlying state-centered conceptions of both democracy and of international law turn out to be self-centered and change-resistant.

Observed this way, the democratic arguments advanced both in Germany and the United States simply ignore the fact that there is not just one state whose right to self-determination deserves respect. Rather, the international legal community is characteristic of the coexistence of various international and domestic legal systems, whereby each domestic legal order enjoys an equal status. From this perspective, the development of an international legal order with primacy of international law over domestic law is necessary particularly because it enables and, at the same time, ensures an equal and peaceful coexistence of the states. ${ }^{83}$ The ultimate goal of international law, then, is neither to establish a universal legal order-which ignores altogether the selfdetermination of domestic constitutional orders-nor to replace the pluralistic developments of different domestic legal orders with a set of substantially homogeneous standards, but rather to equally respect and protect the respective characteristics of different domestic legal systems. ${ }^{84}$

\footnotetext{
${ }^{80}$ For critical analysis of such a solipsistic view, see KeLSEN, ReIne ReCHTSLEHre, supra note 10, at 150; KeLSEN, PRINCIPLES OF INTERNATIONAL LAW, supra note 10, at 581-86.

${ }^{81}$ For a detailed critique, see Shu-Perng Hwang, “Auslegungshilfe” ernst genommen: Zum Spannungsverhältnis zwischen der EMRK und dem GG am Beispiel des beamtenrechtlichen Streikverbots, 108 VerWALTUNGSARCHIV 366, 374-81 (2017); Hwang, supra note $27,123-30$.

${ }^{82}$ For the pluralistic character of American democracy, see, e.g., McGinnis, supra note 39, at 312, 318-19; Rubenfeld, supra note 37 , at $288-89$.

${ }^{83}$ See also Hans Kelsen, Allgemeine StaAtslehre 164-65 (1925); Hwang, supra note 27, 124-27.

${ }^{84}$ This is clearly reflected in the legal system of the European Union. Whereas it is generally recognized that the European Union constitutes a supranational entity in which the member states are especially closely connected to one another, the European Union Law makes clear that the European Union shall "respect the equality of Member States before the Treaties as well as their national identities, inherent in their fundamental structures, political and constitutional, inclusive of regional and local self-government." Treaty on European Union, art. 4, §2 (1992). It furthermore shows that the use of European Union competence "is governed by the principles of subsidiarity and proportionality." Treaty on European Union, art. 5, §1 (1992). It should not be neglected, though, that neither the respect for national identities nor the principle of subsidiarity represents a viewpoint in favor of endless "margin[s] of appreciation" of the member states or even of cultural relativism that straightforwardly rejects any universal standards. Rather, both propositions aim to promote peace and shared values among the member states. Treaty on European Union, art. 3, § 1 (1992). Precisely to this end, both propositions serve to
} 
Precisely to this end, the international legal order is to be understood as a framework order with numerous delegations based on which the domestic constitutional orders are not only allowed, but also obliged, to concretize the international norms so as to fulfill the goals set by international law. ${ }^{85}$ In other words, such a framework order is not full of pre-determined rules and directives. Rather, in pursuit of the equal and peaceful coexistence of domestic legal orders, it leaves enormous room for concretization, interaction, and harmonization. ${ }^{86}$ This is especially true when it comes to international and European human rights law. For example, both the Convention and the Charter of Fundamental Rights of the European Union ("CFR") show that the transnational human rights norms do not intend to establish substantially uniform human rights standards that are ready to replace domestic ones. ${ }^{87}$ Instead, their primary goal is to construct a universal system that promotes the protection of human rights through guaranteeing the human rights standards ensured by the member states ${ }^{88}$ and, under certain preconditions, enabling an individual to make claims against his or her own country. ${ }^{89}$ To this extent, the development of international human rights law encourages, rather than frustrates, substantial inputs from domestic human rights norms, especially through judicial dialogues, ${ }^{90}$ as such dialogues may contribute more effectively to mutual goal-setting without overlooking the diversity of human rights demonstrated in domestic legal systems.

This is not to say, however, that the framework orientation of the international legal order can only be found within the context of international and European human rights law. Rather, as was shown in a number of discussions on European administrative law, many - if not mostprovisions of the European Union in various fields, such as environmental law and telecommunications law, tend not to make detailed regulations by themselves. Instead, they usually set normative goals that are to be fulfilled by the member states, thus empowering the member states to enact norms determining concrete rules or standards so as to implement the European Union

ensure the equal coexistence of the member states, which then necessarily presupposes that all the member states must equally obey a higher law, namely European law. In search of a balance between the principles of subsidiarity and effectiveness, therefore, the European legal system is characteristic of its framework orientation even though its supranational nature makes it distinguishable from other international legal systems.

${ }^{85}$ For this dimension of international legal order, which has been highlighted by Hans Kelsen in many of his works, see, e.g., Shu-Perng Hwang, Zur Aktualität des entmaterialisierten Monismus bei Hans Kelsen: Dargestellt am Beispiel der Entwicklung des Europäischen Verwaltungsverbundes, 139 ARCHIV DES ÖFFENTLICHEN RECHTS 573 (2014) (clarifying the framework character of international legal order through exploring Kelsen's theory of international law).

${ }^{86}$ See generally Hans Kelsen, Peace Through Law 89 (1944):

The norms of international law are not complete norms; to be applied at all they need to be supplemented. This supplementation consists in the designation of the personal element, which is effected by the national legal order. The existence of such national legal orders is presupposed by the international legal order. Only in conjunction with the national legal orders does international law form a significant whole.

${ }^{87}$ See Shu-Perng Hwang, Grundrechte unter Integrationsvorbehalt? Eine rahmenorientierte Überlegung zur Debatte um die Bindung der Mitgliedstaaten an die Unionsgrundrechte, 49 Europarecht 400, 410-19 (2014). But see Huber, supra note 77, at 194-95; Ferdinand Kirchhof, Grundrechtsschutz durch europäische und nationale Gerichte, 64 NEUE JURISTISCHE WOCHENSCHRIFT 3681, 3682-84 (2011).

${ }^{88}$ See, e.g., Convention of Fundamental Rights of the European Union, art. 53, Oct. 2, 2000; Charter of Fundamental Rights of the European Union, art. 53, Oct. 2, 2000. See also Thomas von Danwitz, Art. 53, in KölNER GEMEINSCHAFTSKOMMENTAR zur Europäischen Grundrechte-Charta $§ 19$ (Peter J. Tettinger \& Klaus Stern eds., 2006).

${ }^{89}$ See, e.g., Convention of Fundamental Rights of the European Union, Protocol No. 11, Art. 34, Oct. 2, 2000; Charter of Fundamental Rights of the European Union, Art. 51, §1, Oct. 2, 2000.; TFEU Art. 267.

${ }^{90}$ For transnational judicial dialogues within this context, see Waters, supra note 78, at 554-73; Michael Kirby, International Law - The Impact on National Constitutions, 21 AM. U. INT'L L. REV. 327, 358-63 (2005-2006); Andreas Voßkuhle, Menschenrechtsschutz durch die europäischen, 68 RECHT DER ARBEIT 336, 337 (2015); Oliver Lepsius, Grundrechtspluralismus in Europa, in Strukturfragen des Grundrechtsschutzes in Europa. Grundrechtecharta - GRUNDRECHTSBINDUNG -

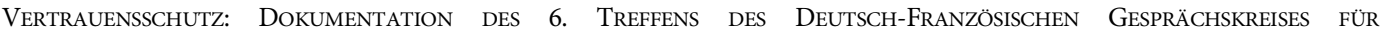
ÖFFENTLICHES RECHT 45, 64 (Johannes Masing et al. eds., 2015); Koen Lenaerts, Exploring the Limits of the EU Charter of Fundamental Rights, 8 Eur. CONST. L. REv. 375, 398 (2012). 
law in a way that is most suitable for domestic needs. ${ }^{91}$ Numerous examples show that it is the framework setting rather than predetermination that characterizes European administrative law. ${ }^{92}$

Particularly the example of international human rights law, though, shows the complementary relationship between human rights protection and democracy. In pursuit of a more comprehensive and high-level protection of human rights, international human rights law does not just merely protect individuals against the abuse of public powers-both on the international and the national level - but also in this way enables individuals to realize their freedom in the sense of self-determination. To the extent that democracy is to be understood as a form of government, which not only follows majority rule but also cares about minority rights, ${ }^{93}$ the development of international human rights law is able to contribute to the promotion of democracy precisely in the sense that it facilitates communication between majorities and minorities. Thus conceived, both the insistence on the absolute supremacy of the German Basic Law and the adherence to the impenetrability of the American Constitution tend to neglect the rights-promoting dimension of a pluralistic democracy to the extent that they adhere to a state-centered conception of democracy. Moreover, from the perspective that international law constitutes a framework order that aims at ensuring an equal and peaceful coexistence of the states, such a state-centered approach to international legal system - be it dualism or exceptionalism-inevitably runs the risk of misjudging the nature and task of international law. ${ }^{94}$

\section{E. Conclusion}

From a comparative perspective, this Article examines the German and the American democratic arguments against an overreliance on international and foreign law in constitutional interpretation. In exploring the democratic concerns expressed in German and American discussions, it focuses especially on the contrast between German dualism on the one hand and American exceptionalism on the other. It shows that, while the German dualists and the American exceptionalists base their arguments on different understandings of democracy, they share the viewpoint that democracy can only be realized on the national level — whereas international law aims at uniformity and thus inevitably runs counter to democratic self-governance and self-determination of the states. Precisely in this sense, it can be said that there is no qualitative, but rather only a quantitative distinction between German and American democratic arguments. ${ }^{95}$ Thus conceived, the alleged contrast between the principle of open statehood emphasized again and again by German constitutional law scholars and the Constitutional Court, and the idea of American exceptionalism embraced by a number of critics of the use of foreign law lies only in the extent to which the reference to international or foreign law in interpreting the domestic Constitution is deemed

\footnotetext{
${ }^{91}$ For the framework character of European administrative law, see generally Oliver Lepsius, Hat die Europäisierung des Verwaltungsrechts Methode? Oder: Die zwei Phasen der Europäisierung des Verwaltungsrechts, in DAS EUROPÄISCHE Verwaltungsrecht in der Konsolidierungsphase, Die Verwaltung Beineft 10 179, 192 (Peter Axer et al. eds., 2010); Eberhard Schmidt-Aßmann, Der Verfahrensgedanke im deutschen und europäischen Verwaltungsrecht, in GRUNDLAGEN DES VerWALTUNGSRECHTS, BD. II §§ 15-16 (Wolfgang Hoffmann-Riem, Eberhard Schmidt-Aßmann \& Andreas Voßkuhle eds., 2008).

${ }^{92}$ For detailed analysis, see Hwang, supra note 85, at 586-93. To this extent, therefore, the analysis of the nature and task of international law in this article is not confined to international human rights law.

${ }^{93}$ For a pluralistic understanding of democracy, which puts emphasis on individual freedom and thereby on the communication and compromise between majorities and minorities, see HANS Kelsen, Vom WeSEn UNd Wert DER Demokratie (1929) 3-13, 53-58 (2d ed. 1963).

${ }^{94}$ See also von Bogdandy, supra note 73, at 298 (arguing that international law "is so far the only instrument to provide some level of say for foreign persons affected by the adoption of measures of another polity" and that a state that is open to international law "is therefore not limiting its democratic life, but rather realizes a new dimension of it"); Kirby, supra note 31, at 458 (maintaining that the function of international human rights law lies [also] in the protection of fundamental rights of minorities).

${ }^{95}$ But see Krieger, supra note 71, at 320-24 (highlighting the contrast between American exceptionalism and the German principle of open statehood in historical perspective).
} 
legitimate and justifiable. According to German mainstream opinion, the absolute supremacy of the Basic Law suffices to safeguard the constitutional identity and democratic self-determination of Germany. From the perspective of American exceptionalism, though, only an overall rejection of foreign resources serves to retain the uniqueness of American democracy and the identity of the American Constitution.

The comparison of the democratic arguments in Germany and the United States reveals that it is the state-centered conception of democracy that contributes to stereotypes of international law and international legal system. Based on these stereotypes, the relationship between international law and domestic law has always been understood as an irreconcilable contrast, whereby international law threatens to undermine national constitutional democracy, especially when it intends to construct a universal system of human rights protection which enables the development of transnational constitutionalism. As illustrated in this Article, however, those who embrace such a view on the relationship of international law and domestic constitutional law tend to oversimplify democracy as self-determination of their own states, and therefore neglect that the significance of international law lies in the equal protection of the self-determination of all the states of the world community. Observed this way, the alleged tension between international law and constitutional democracy has not resulted from the inevitably anti-democratic character of international law, but rather from the one-sided, namely self-centered, approaches to democracy_-which are reflected both in German dualism and American exceptionalism.

Cite this article: Hwang S-P (2019). Foreign Law, Democracy, and Constitutional Interpretation: A German-American Comparison. German Law Journal 20, 1119-1139. https://doi.org/10.1017/glj.2019.80 